

\section{Sumário}

Editorial: ConstituCiOnalismo latino-AMERICANO: O QUE TEMOS EM COMUM? .15

Editorial: Constitucionalismo Latinoamericano: ¿Qué TENEMOS EN COMÚN? 17 Luís Roberto Barroso e Patrícia Perrone Campos Mello

Seção I: Poder Constituinte

As Constituições latino-AMERICANAS ENTRE A VIDA E A MORTE: POSSIBILIDADES E LIMITES DO PODER DE EMENDA

Luís Roberto Barroso e Aline Osorio

Criação constitucional sem Poder Constituinte: Os limites conceituais do poder de SUBSTITUIÇÃO OU REVISÃO DA CONSTITUIÇÃO

Carlos Bernal Pulido

Quem Conta Como naÇão? A ExClusão de temáticas LGBTI nas asSEMbleias CONSTituintes de Brasil e Colômbia

Rafael Carrano Lelis, Marcos Felipe Lopes de Almeida e Waleska Marcy Rosa

Em Defesa da PaRTicipaÇão: ANálise da iniciativa POPUlar Para alteraÇão da Constituição no Brasil E No EquAdor

Ilana Aló Cardoso Ribeiro e Lílian Márcia Balmant Emerique

Reflexões críticas sobre o Processo Constituinte Equatoriano de Montecristi (2007-2008)

E. Emiliano Maldonado

SeÇão II: Jurisdição Constitucional e Democracia

LA REVISIÓN JUDICIAL EN DEMOCRACIAS DEFECTUOSAS 154 Roberto Gargarella

Constituição E PluRalismo JURÍdico: A POSIÇÃo PARTICUlar do Brasil NO CONTEXTO LATINO-AMERICANO

Ana Paula Gonçalves Pereira de Barcellos

As CONSTITUiÇões LATINO-AMERICANAS PELAS LENTES DAS CORTES CONSTITUCiONAIS: A FORÇA NORMATIVA E O ROMANTISMO DOS PREÂMBULOS 185 Arnaldo Sampaio de Moraes Godoy e Carlos Frederico Santos 
REDES SOCIALES, JUSTICIA CONSTITUCIONAL Y DELIBERACIÓN PÚBLICA DE CALIDAD: LECCIONES DEL Plebiscito por la PAZ EN Colombia...........................................................203 Jorge Ernesto Roa Roa

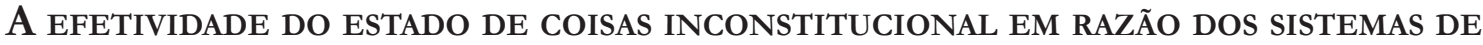
monitoramento: uma aNÁlise comparativa ENTRE Colômbia E Brasil 218

Aléssia Barroso Lima Brito Campos Chevitarese, Ana Borges Coêlho Santos e Felipe Meneses Graça

Seção III: Constitucionalismo Transformador e "Ius Constitucionale Commune" na AmÉRica LATina 231

O MANDATO TRANSFORMADOR DO Sistema INTERAMERICANO: LEgALIDADE E LEGITIMIDADE DE UM PROCESSO JURISGENÉTICO EXTRAORDINÁRIO 233 Armin von Bogdandy

CONSTITUCIONALISMO, TRANSFORMAÇÃO E RESILIÊNCIA DEMOCRÁTICA NO BRASIL: O IUS Constitucionale Commune na América Latina tem uma Contribuição a oferecer? .. 254 Patrícia Perrone Campos Mello

UM PROJETO COMUM PARA A AMÉRICA LATINA E OS IMPACTOS DAS EMPRESAS EM DIREITOS HUMANOS .287

Danielle Anne Pamplona

O papel da Corte Interamericana de Direitos humanos na construção dialogada do Ius Constitutionale Commune na América Latina..............................................303 Ana Carolina Lopes Olsen e Katya Kozicki

Seção IV: Novo Constitucionalismo Latino-Americano

O papel da Corte Interamericana de Direitos humanos na construÇão dialogada do Ius Constitutionale Commune na América Latina.................................................334 Roberto Viciano Pastor e Rubén Martínez Dalmau

¡Que viva El Estado Plurinacional!: ¿Y lo socioambiental? 351 Anibal Alejandro Rojas Hernández, aula Harumi Kanno, Heline Sivini Ferreira e Adriele Fernanda Andrade Précoma

O NOVO CONSTITUCIONALISMO LATINO-AMERICANO: ANÁLISE MARXISTA DA INVISIBILIZAÇÃO DA LUTA DE CLASSES NAS INVESTIGAÇÕES JURÍDICAS CRÍTICAS .365

Daniel Araújo Valença, Ronaldo Moreira Maia Júnior e Rayane Cristina de Andrade Gomes

O NOVO CONSTITUCIONALISMO LATINO-AMERICANO: ANÁLISE MARXISTA DA INVISIBILIZAÇÃO DA LUTA DE CLASSES NAS INVESTIGAÇÕES JURÍDICAS CRÍTICAS .382

Adriele Andrade Précoma, Heline Sivini Ferreira e Rogério Silva Portanova 
O direito À ÁGUA NAs Constituições da América do Sul: Elementos comuns e traços DISTINTIVOS.

Thiago Rafael Burckhart e Milena Petters Melo

Direitos Humanos na América Latina: avanços e desafios inerentes À atual CONJUNTURA POLÍTICA

Paulo Renato Vitória e Gabriela Maia Rebouças

O Novo Constitucionalismo na América latina e Caribe, e a construção do direito À SAÚDE

Alethele de Oliveira Santos, Maria Célia Delduque e Moacyr Rey Filho

A qualidade da educaÇão para a EFETIVaÇão E Consolidação do novo CONSTITUCIONALISMO LATINO-AMERICANO NO EQUADOR E NA BOLÍVIA.

Manuel Rodrigues de Sousa Junior e Luigi Bonizzato

A diversidade Cultural segundo o entendimento da Corte InTERAmericana de Direitos Humanos e o Novo Constitucionalismo Latino-Americano transformador. 476 Bianor Saraiva Nogueira Júnior, Deicy Yurley Parra Flórez e Ulisses Arjan Cruz dos Santos

UN APORTE A LA PROTECCIÓN DE LOS DERECHOS HUMANOS EN LATINOAMÉRICA: LA ACTIVIDAD del Ombudsman Criollo en tribunales de justicia 493 Juan Pablo Díaz Fuenzalida

SEÇÃo VI: Povos Indígenas

El DERECHO FUNDAMENTAL A LA IDENTIDAD CULTURAL DE LOS PUEBLOS INDÍGENAS: UN DERECHO-MATRIZ Y FILTRO HERMENÉUTICO PARA LAS CONSTITUCIONES DE AMÉRICA LATINA: LA JUSTIFICACIÓN 514 Juan Jorge Faundes

Povos INDígenas E A (AUSÊNCIA DE) JUSTIÇA DE TRANSIÇÃo BRASILEIRA: UMA ANÁLISE À LUZ DO CONSTITUCIONALISMO PLURALISTA LATINO-AMERICANO Jamilly Izabela de Brito Silva e Sílvia Maria da Silveira Loureiro

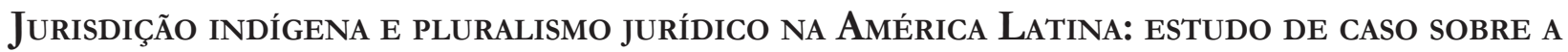
JUSTIÇA WAIWAI .558 João Vitor Cardoso e Luiz Guilherme Arcaro Conci

O NOVO CONSTITUCIONALISMO LATINO-AMERICANO E OS POVOS INDÍGENAS: A VisÃo Do DiREITO A PARTIR dOS CALEIDOSCÓPIOS E DOS MONÓCUlOS 577 Lucas Silva de Souza, Valéria Ribas do Nascimento e Isadora Forgiarini Balem 


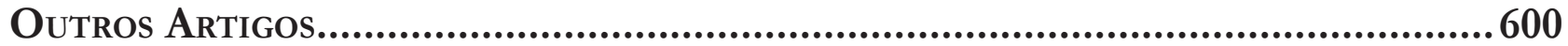

BUILDING TRUST IN COLLABORATIVE PROCESS OF VILLAGE FUND POLICY IMPLEMENTATION (A Case Study at Luwuk District of Banggai Regency) .........................................602 Rahmawati halim 


\title{
Building trust in collaborative process of village fund policy implementation (A Case Study at Luwuk District of Banggai Regency)*
}

\author{
Construção de confiança no processo \\ colaborativo de implementação da política \\ do "village fund " (Um estudo de caso no \\ distrito de Luwuk, na região de Banggai)
}

Rahmawati halim**

\begin{abstract}
Building trust is one of dimensions of collaborative governance process beside face-to-face dialogue, commitment to process, shared understanding, and short-term achievements. This study analyzed and described the dimension of building trust in the implementation of village fund policy in the perspective of collaborative governance process theory. This research was conducted in Tontouan Village, which has received fund village program since 2015. Empirical evidence shows that the trust that actors have in collaborative governance process can be beneficial in supporting the success of actor support and cooperation, commitment and successful policy implementation. However, collaborative governance-related literature reveals that there is little research on building trust in policy implementation, especially village fund policy implementation. The results of this study indicate that building trust between actors in the collaborative governance process greatly contributes to the effectiveness of village fund policy the implementation in Luwuk Sub-district, Banggai Regency.
\end{abstract}

Keywords: building trust, collaborative governance process, village fund.

* Recebido em 14/06/2019 Aprovado em 16/08/2019

** Public Administration - Makassar, Indonesia. E-mail : rahmawatirahmawatirahmawati5@ gmail.com

\section{Introduction}

Village fund policy in Indonesia is one of the programs of the Central Government to improve community empowerment and equity even at the village level. However, there are still various problems in implementing village fund policies, for example weak trust among actors in implementing village fund policies and weak capacity of village governments to manage limited village funds, and less transparent, participatory and accountable system of village governance. One alternative solution in solving these problems is improving governance by involving various stakeholders, village fund monitoring and escort team and the community in order to monitor the implementation of village fund policies. This is very realistic considering the relatively limited capacity of village governments. Thus, village governments 
need support from various parties in order to achieve success in implementing village fund policies. Collaborative governance theory is an approach that can be used in policy implementation by involving various components of society that work together to support each other because of the limited resources that an organization has. Collaborative governance process covers several dimensions, namely; face to face, building trust, commitment to process, shared understanding, and short-terms achievements, even collaborative governance is seen as a government platform in resolving complex problems related to public services. This study investigates building trust in village fund policy implementation based on the perspective of collaborative governance process. Some research results explain the importance of the perspective of collaborative governance. Experts have the same perspective that collaborative governance can enhance collaboration between various stakeholders, support the resolution of various complex problems caused by limited resources owned by the government, and make the expected changes in public sector services. Research conducted by Emerson, Nabatchi, \& Balogh, found that collaborative governance is useful to unite the various differences of thought that exist among stakeholders, especially public, private, and nonprofit sector actors to achieve core objectives, including policy settings, policy implementation and coordination in controlling various tasks related to public services. The collaborative process perspective can basically increase actors' commitment in policy implementation and actors' cooperation or integrative interests in collaboration. The collaborative process can be carried out through three stages, namely; (1) problem setting, (2) direction setting, and (3) implementation. Several previous studies showed that the theory of collaborative governance has an important meaning in supporting the successful achievement of effective and efficient goals of public and private sector organizations.

Management of village fund in Luwuk sub-district of Banggai Regency still faces various problems in terms of (a) capacity of village government human resources in implementing village fund policies, (b) inadequate infrastructure to support village fund programs; (c) support and readiness of village government in the preparation of the Village Medium Term Development Plan, Village Government Work Plan, Village Income and Expenditure Budget (APBDesa), budget planning and budget allocation for village funds; and (d) actors' commitment in supporting the implementation of a relatively low village fund activity program. The current phenomenon shows that the Village Government is still faced with various challenges, especially those related to the utilization of village budget funds that have been going on since 2015 that seem less effective.

This study aims to analyze and describe aspect of building trust in the implementation of village fund policies based on the theory of collaborative governance. The study was conducted in a village that has its own uniqueness, namely Tontouan village, Luwuk Sub-district, Banggai Regency. The village is located in the capital city of Banggai regency, Luwuk, which can be reached in about twenty minutes. Typologically, this village consists of hilly areas and the community still adheres to strong customs and traditions, and one of the principles that is made into the principle of people's lives is "momposa'angu tanga, membulakon tano" (Saluan language). That principle means that "village development requires agreement through community consultation". Basically, the principle is relevant to the theory of collaborative governance because it aims to be an adhesive in increasing the enthusiasm and cooperation of all elements of society in achieving mutual expectations in policy implementation. Collaborative governance focuses on public policy and public management and one aspect of collaborative governance is building trust.

The effort to build trust in the government sector requires at least five important elements, namely; (a) performance, namely realizing previously set targets in accordance with public perceptions; (b) institutional design, namely organizational character seen from the mechanism of community involvement, governance structure, and political system (election); (c) attributes of government officials which include; behavior that is appropriate to ethics, integrity, competence, and willingness (benevolence), (d) a conducive environment includes political stability, economic welfare, public trust in general, and trust in the government; (e) trustworthy government actors consisting of; individual characteristics, such as demographics, 
parties, affiliations, and political ideology. In a trust research journal, Hamm et al., found that there are six aspects that strengthen trust, namely; dispositional trust, care, competence, confidence, procedural fairness and salient values similarity. Each of these elements is basically different from each other, but correlates with each other, which are useful for encouraging collaboration between actors and influencing the increase in satisfaction and knowledge and experience of stakeholders (trustor). Therefore, trust is a core element that can increase public willingness to participate and interact with the government. Therefore, this study outlines the extent to which building trust influences the implementation of village fund policies. With the development of actors' trust involved in policy implementation, it is expected that village fund management will be more effective, efficient and accountable.

\section{Literature review}

Collaborative public management is "a concept that describes the process of facilitating and operating in multi-organizational arrangements to solve problems that cannot be solved or easily solved by single organizations. Collaborative theory is one effective approach to solving complex problems, or solving problems that have not had the right solution. Many experts in the field of collaborative governance argue that complexity and uncertainty characterized as complex problems are very appropriate if resolved through the involvement of various parties who are directly responsible and influential in solving problems, as well as individuals who have relevant expertise in dealing with problems faced. In the past few decades, collaborative governance models have been very popular as an alternative for governments that still adopt traditional bureaucratic governance patterns. In this case, collaborative governance emphasizes efforts to bring together a variety of objectives of stakeholders from various public, private, and non-profit sector actors for a single purpose, including policy making, policy implementation, or coordination in controlling public service tasks.

In a collaborative process, a framework that is very useful for solving problems is through a collaborative process. This approach considers the process to be iterative and cyclical rather than linear. Collaborative governance will increase actor commitment in carrying out responsibilities and has integrative interests in collaboration.

Mizrahi, et al found that trust has a positive effect on increasing participation, and participation can improve performance. Trust, specifically in the organizational context is constituted as one of the pillars on which employment relations are built. The bond of trust to the organizational context is of particular importance in understanding the relations between management and employee.

Trust is one dimension that cannot be separated in the theory of public administration. In public administration, there is an increase in attention for the public's perception of government, and trust more in particular, and for sure that there was some researches ranged from country studies. Trust is an element that can foster the participation and commitment of actors in policy implementation. This article is based on Mayer's et al (1995) theory, which explains that the model that can be used to develop trust in the public sector is an integrative model of organizational trust. Trusted public organizations are organizations that have competence, commitment and benevolence. The following is a scheme related to the analysis of aspects of building trust in the perspective of the collaborative governance process: 


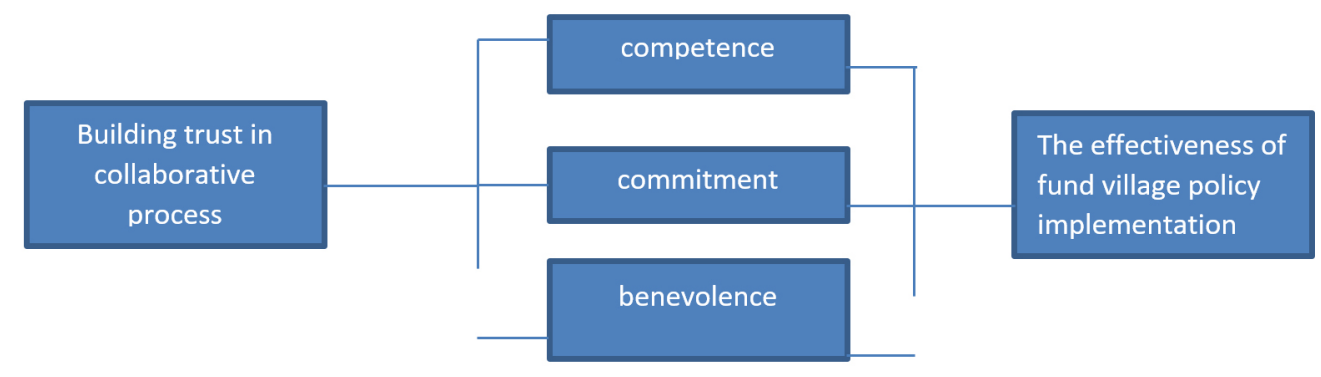

Figure 1. Research model

\section{Methods}

The approach used in this study is a qualitative approach with a case study strategy. Data collection methods include interviews, observation, and documentation analysis. Interviews were carried out on informants who were selected by purposive sampling based on the consideration that they knew precisely the problem of village fund management. To obtain data in this study, several informants were needed as key informants taken by purposive sampling, including Community and Village Empowerment Agency, Head of Luwuk Sub-District, Head of Tontouan Village, Village Consultative Body (BPD), and Village Fund Supervisor and Supervisor Team. Observations were carried out directly at the study site in Tontouan village. This village has its own uniqueness with the strong kinship and custom of the Saluan Tribe. This village is located on the hill of Luwuk as the capital of Banggai Regency. The people who live in this village have a good harmonious relationship. Tontouan Village has received village funds since 2015, and many village programs have been implemented and received awards from the local government. Therefore, this study analyzes the aspect of building trust in the implementation of development programs and community empowerment through village funds. Data from interviews, observations, and documentation study was analyzed using an interactive model analysis which includes four steps; data collection, data condensation, data display, and conclusion drawing.

\section{Research findings and discussion}

Contextually, village fund policy aims to improve rural development and empower village communities. In order for village funds to be beneficial where village funds really coexist with village communities, at least $70 \%$ of village funds are used for physical, economic and socio-cultural development, the remaining $30 \%$ is used for routine/operational expenditure and community empowerment. Based on the real needs and provisions on portion distribution $(70 \%: 30 \%)$, this fund can be used to the maximum extent possible for empowerment for the welfare of rural communities.

The implementation of village funds has been confirmed by Government Law No.43 of 2014 concerning the rules for implementing Law Number 6 of 2014 which clearly describes village funds. In this article, it can be ascertained that the implementation program is a very important dimension because it provides certainty whether the program will be implemented seriously or not. The results of the study indicate that the Tontouan village government has sought to make the program successful because the village fund program has close relevance to achieving effectiveness and efficiency. However, it can be said that the implementation of the program is not easy to realize because of the uncertainty and complexity of people, and the environment is also always more influential in determining the success of village funds. 


\subsection{Competency}

However, overall the implementation of successful village fund policies requires the competency of actors involved in village forums to work together and support each program that has been established. Actors directly involved in implementing village fund policies in Tontouan Village are (1) Village head. The village head functions as the person in charge of the success of village fund management with the support of all elements of village government. (2) The BPD functions as the controller of all village fund management activities, especially in the aspect of evaluation and monitoring of village funds; (3) Sub-district head functions as a facilitator and support agent in setting various program activities that are in accordance with the interests and needs of the local community. Sub-district head has a very important role in the success of the village fund program as a mediator in achieving the effectiveness of the village fund program; (4) Community and Village Empowerment Agency has a function as a representative of the government that analyzes and assists program proposals and funding allocated to the village, and is responsible for ensuring that reports on the use of the village budget are in accordance with their designation and check the financial administration of village funds. (5) The Village Fund Advisory Team and Supervisors play an important role in overseeing the process of village fund program management, helping to plan and prepare village fund financial reports. The five actors involved in the collaborative process worked together to help the Tontouan village government manage village funds. The success of managing village funds is largely determined by the commitment and synergy of the actors. Therefore, the ability of actors in program implementation is very necessary to achieve the effectiveness of village fund management. The following are the results of interviews about actor competencies:

"Actor competencies such as in the preparation of the program have been good, this can be proven in a village forum
meeting where all actors were invited and involved in village program funding activities. Actor competency is needed to
encourage village community trust and participation" (Informant 1)

Based on information obtained from the informant, it can be stated that basically the competence of actors in collaboration process of policy implementation is very important because it can encourage community to participate in the activities specified.

The results of the interview were strengthened by one of the village officials who stated as follows:

"The competency of actors in managing village funds is needed so that all village fund activities can achieve effective results" (Informant 2).

The results of the data reduction show that basically the competence of actors in the collaboration process of the implementation of village fund policies is very necessary. In addition, the competencies in question include (1) program planning competence, (2) budgeting competence, (3) program evaluation competence, and (4) competence in supervision of village fund, and (5) competence in preparing village financial accountability reports. This can be seen from the results of interviews with one of the informants who stated:

"Village fund management cannot succeed without the support of all parties who are directly responsible for the smooth running of the program, such as the Village Head and BPD officials, the sub-district, the Community and Village Empowerment Agency, and the Supervisory Team. Each actor must have competence in the preparation of strategic plans, implementation, supervision, evaluation, monitoring, and preparation of financial accountability. If the actor implementing the activity program has these competencies, public trust and the success of the program can be improved (informant 3).

Based on the results of observation interviews and document reviews, each actor has a role in formulating programs and providing material in socialization and budgeting. The results of the review of village fund reporting documents indicate that Tontouan Village was one of the pilot villages in the preparation of village fund activities and financial reporting programs. This success is basically due to the competency support of the actors involved in the collaborative process of implementing village fund policies in Tontouan 
Village, Luwuk Sub-district, Banggai regency. The results of this study are relevant to the results of Mayer's study, et al. (1995) which found that actor competence greatly determines the success of the organization in implementing policies that have been established and become trusted institutions. Thus, propositions can be built on the aspects of actor competence in building trust as follows:

Proposition 1: Actor competency is needed in supporting the process of implementing village fund policies, so that the better the competencies of the actors involved in the collaborative process of implementing village fund policies, the more public trust will be built.

\subsection{Commitment}

In the case of collaborative government contingency theory, Ansell and Gash concluded that if there is a significant power / resource imbalance between stakeholders, so that stakeholders cannot participate in a meaningful way, effective collaborative governance requires commitment to positive empowerment strategies and representation of weaker or less fortunate stakeholders.

The collaboration process is the core process of collaboration that aims to achieve predetermined results. The collaboration process determines the success of the overall policy implementation program. The better the collaborative process, the more successful the program will be. The collaboration process includes several aspects, namely; How to build trust among collaborators, How to build commitment in the collaboration process; Various understandings of the mission and problems faced, and identifying shared values in collaboration; temporary result, by seeing how to achieve initial success, strategic planning, and the discovery of facts; face-to-face dialogue in this case to negotiate with other better actors. The results of the study indicate that the trust between actors has been well established as evidenced by the growing commitment of actors in managing village fund activities programs together.

The results of interviews conducted with several key informants are as follows:

“The actor's commitment in the process of managing village funds is needed to build public trust" (Informant 4).

The results of the interview indicate that the actor's commitment is closely related to building public trust. This is reinforced by the results of interviews with one of the staff of the Community and Village Empowerment Agency as follows:

"As a mediator for the successful management of village funds, the commitment of actors involved in managing village funds is urgently needed, so that community participation increases. The high commitment of the parties involved greatly guarantees the success of the village fund program and financial accountability" (Informant 5).

This opinion shows that the actor's commitment, besides being able to foster public trust, can also function as a guarantor of the success of the program and financial accountability of village funds. Thus, proposition 2 can be proposed in this study as follows:

Proposition 2: The actor's commitment in the collaborative process is needed to achieve successful implementation of the village fund policy, generating community participation in supporting the management of village funds.

\subsection{Benevolence}

In this study, benevolence is interpreted as a virtue of the actors in implementing village fund policies to comply with all procedures and mechanisms for managing village funds based on applicable laws and regulations. Benevolence is closely related to the ability of actors to try to control themselves following each 
stage in village fund management. The results of the study on benevolence show that the virtues of actors to follow the applicable ethics and norms in managing village funds play an important role in building trust. This can be seen from the results of interviews conducted with one of the sub-district heads as follows:

"Benevolence of actors involved in supporting the management of village funds in Tontouan Village is very important because it will create community trust in the Tontouan village" (informant 6).

The results of the interview were confirmed by one of the Tontouan Village officials who stated as follows:

"Benevolence is the most important part of building the trust of the actors involved in managing village funds because it is related to finance, all actors must comply with all applicable regulations and norms" (informant 7).

The collaborative process of managing village funds requires the support of various actors so that the management of village funds can be successful. With different backgrounds, actors will certainly have a variety of perceptions and interests, but building trust requires "benevolence" of all actors to jointly implement all program activities that have been agreed upon at the deliberation forum.

The benevolence of actors can be seen in the form of following all the processes and stages in managing village funds for example; preparation of budget plans and activities based on applicable laws and regulations, budget discipline and financial accountability of village funds. Benevolence of actors can foster public trust in the credibility of the program set together. This can be seen from the results of interviews with the Head of Tontouan Village as follows:

"Benevolence is very important to create public trust in the village government and all persons involved in managing village funds" (Informant 8).

The same was stated by the Chairperson of the Tontouan Village BPD as follows:

"The benevolence of all officials and parties involved in the village discussion forum will be beneficial to build community trust, transparency, participation, and accountability of all components of society" (informant 9).

The results of observations and document reviews indicate that all the stages that have been set up in the village discussion forum to establish a program of activities and budgets are well implemented. All members are involved and committed to carrying out all applicable provisions in managing village funds. Furthermore, the third proposition in this study is as follows:

Proposition 3. The benevolence of actors in implementing policies will ensure the success of activity program. The better the benevolence of actors, the better trust, transparency, participation and accountability will be built.

\section{Discussions}

Perspective of collaborative governance strongly emphasizes the importance of building trust as one component in the collaborative process. Ansell and Gash explain that collaborative governance focuses on public policy and issues related to public problems. In a collaborative process, they assert that collaborative processes are a form of cooperation that are interrelated with each other which includes; face to face dialogue, building trust, commitment to process, shared understanding, and short-terms achievements. Susskind and Cruikshank illustrate that the actors involved in the collaborative process seek to build consensus through various negotiations and stages of policy implementation. Edelenbos identifies that there are three processes that need to be carried out in the collaboration process, namely; preparation, policy development, and policy setting, and each of these stages has its own characteristics. The collaboration model is an important 
part that needs attention because it is related to the change in strategy applied in the context of the collaboration process. Vangen and Huxham explained that building trust is not only solely related to building negotiations and communication, but rather needs to build the commitment and trust of all actors. Ansell and Gash propose the proposition that building trust requires a considerable amount of time, requiring the actor's long-term commitment to achieve collaborative results. They stated that if there were differences in views of opposing actors, policymakers needed to develop effective budgets to improve actor trusts. If it does not work, the actors should not be involved in the collaborative process.

This thought indicates that building trust requires adequate time and costs, and evaluations carried out in the long term. This study found that building trust in the collaborative process requires the main elements, namely; actor competence, commitment and benevolence. The results of this study prove that the actors are not easy to build trust because it requires repeated negotiations and agreement of all actors in policy implementation.

The management of village funds established jointly through a village discussion forum requires trust because it will determine the success and effectiveness of village funds. The better the public's trust in the actors involved in program management, the more helpful it will be in achieving successful implementation of village fund policies. The following is an empirical model of the results of research on building trust in the collaborative process:

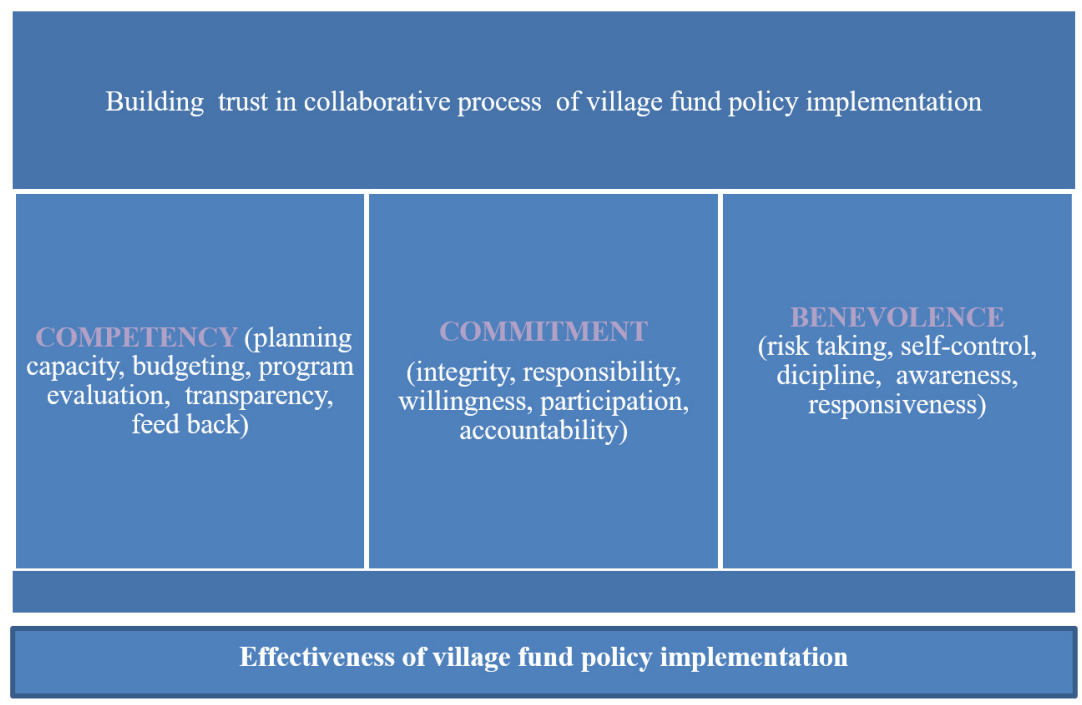

Figure 2. Empirical facts

Source: Authors, 2018.

\section{Conclusion}

The success of collaborative processes in implementing village fund policies is largely determined by the ability of actors to build public trust. Building trust as one aspect of the collaborative process is not an easy matter because it requires time and evaluation as well as an adequate budget to prove whether the actors involved in implementing village fund policies can be trusted or not.

This study concludes that adequate competency of actors in preparing program planning, implementation, evaluation, and monitoring and transparency in the preparation and reporting of budgets is a noteworthy aspect by leaders of public sector institutions. Public sector institutions responsible for program and financial management need to determine which actors have sufficient competencies to support the effectiveness of the program. The better the competency of the actors, the more public trust in the imple- 
mentation of policies can be grown.

In addition to competency, the actor's commitment also greatly influences the trust of actors and public participation to support the implementation of village fund policies. High commitment can be realized in the form of involvement in the completion of work, support of resources, labor, costs, and time voluntarily in completing the program set together. If the actor has a high commitment and follows every procedure and mechanism that has been set, public trust in the integrity of the actor will be built.

Finally, benevolence of actors is an aspect needed to build trust. The better the virtues of the actors involved in the collaborative process of managing village funds, the higher community trust can be grown. In the end, the community will participate in all stages of activities that have been mutually agreed upon. This study implies that aspects of building trust are one of the aspects that cannot be separated in a collaborative process based on the theory of collaborative governance. Building trust between actors is useful for achieving effectiveness in implementing village fund policies.

\section{References}

ANSELL, C.; GASH, A. Collaborative governance in theory and practice. Journal of Public Administration Research and Theory, v. 18, pp. 543-571, 2008.

ANSELL, C.; GASH, A. Collaborative Platforms as a Governance Strategy. Journal of Public Administration Research And Theory, v. 28, n. 1, pp.1-17, 2017.

CHRISTENSEN, T.; LAEGREID, P. Trust in government the relative importance of service satisfaction, political factors and demography. Public Performance and Management Review, v. 28, n. 4, 487-511, 2005.

EDELENBOS, J. Institutional implications of interactive governance: Insights from Dutch practice. Governance: An International Journal of Policy, Administration and Institutions, v. 18, pp. 111-134, 2005.

EMERSON, K.; Nabatchi, T. Collaborative governance regimes. Washington: Washington, Georgetown University Press, 2015.

EMERSON, K.; NABATCHI, T.; BALOGH, S. An integrative framework for collaborative governance. Journal of Public Administration Research and Theory, v. 22, pp. 1-29, 2012.

FERREIRA, T.; KEATING. J.; SILVA, I. Competing Values in an Uncertain Environment: Managing the Paradox. Shreveport:ISSWOV - International Society for the Study of Work \& Organizational Values, 2010.

GLASBERGEN, P.; DRIESSEN, P.P.J. Interactive planning of infrastructure: The changing role of Dutch project management. Environment and Planning C: Government and Policy, v. 23, pp. 263-277, 2005.

HAMM, J.A.; HOFMANN, L.; TOMKINS, A.J.; BORNSTEIN, B.H. On the influence of trust in predicting rural land owner cooperation with natural resource management institutions. Journal of Trust Research. Routledge, v. 6, 2016.

HAMM, J.A. Trust, Trustworthiness, and Motivation in the Natural Resource Management Context. Journal Society \& Natural Resources: An International Journal, v. 30, n. 8, pp. 919-933, 2017.

KORUPSI, K. P. Laporan Kajian Sistem Pengelolaan Kenangan Desa: lokasi Dana Desa dan Dana Desa. Jakarta: Direktorat Penelitian dan Pengembangan, 2015.

MARLOWE, J. Part of the solution or cogs in the system?: The origins and consequences of trust in public administrators. Public Integrity, v. 6, n. 2, pp. 93-113, 2004. 
MAYER, R. C.; Davis, J.H. The effect of the performance appraisal system on trust for management: a field quasi-experiment. Journal of Applied Psychology, v. 84, pp. 123-136, 1999.

MILES, M. B.; HUBERMAN, A. M.; SALDANA, J. Qualitative Data Analysis: A Methods Sourcebook, 3. Ed. Califórnia: SAGE Publications, 2014.

MIZRAHI, S.; VIGODA-GADOT, E.; COHEN, N. Trust, Participation, and Performance in Public Administration: An Empirical Examination of Health Services in Israel. Public Management Review, v. 33, n. 1, pp.7-33, 2014.

OSBORNE, S.P. The New Public Governance; Emerging Perspectives on the Theory and Practice of Public Governance. Routledge: London, 2010.

RING, P.S.; VAN DE VEN, A.H. Development Processes of Cooperative Interorganizational Relationships. Academy of Management Review, v. 19 n. 1, pp. 90 - 118, 1994.

SUSSKIND, L.; CRUIKSHANK, J. Breaking the impasse: Consensual approaches to resolving public disputes. New York: Basic Books, 1987.

THOMSON, A.M.; Perry, J.L. Collaboration Processes: Inside the Black Box. Public Administration Review, Special issue, pp. 20-32, 2006.

THOMPSON, A.M.; PERRY, J.L.; MILLER, T.K. 2009. Conceptualizing and measuring collaboration. Journal of Public Administration Research and Theory, v. 19, pp. 23-56, 2009.

Undang-Undang Nomor 23 Tahun 2014 tentang Pemerintahan Daerah, Lembaran Negara Nomor 244 Tahun 2014, Tambahan Lembaran Negara Nomor 5587, Kemendagri, Jakarta.

Undang-Undang Nomor 6 Tahun 2014 tentang Desa, Lembaran Negara Nomor 7 Tahun 2014, Tambahan Lembaran Negara Nomor, 5495, Kemendagri, Jakarta.

VANGEN, S.; HUXHAM. C. Nurturing collaborative relations: Building trust in interorganizational collaboration. Journal of Applied Behavioral Science, v. 39, pp. 5-31, 2003. 
Para publicar na revista Brasileira de Políticas Públicas, acesse o endereço eletrônico www.rbpp.uniceub.br

Observe as normas de publicação, para facilitar e agilizar o trabalho de edição. 